\title{
Göçün 60. yılında Türk-Alman Sinemas1: Gözde Naiboğlu ile Röportaj
}

\author{
Ayla Torun ${ }^{1}$
}

Türkiye ile Federal Almanya arasında ilk 'misafir işçi' anlaşmasının yapıldığı 1961 yılının üzerinden 60 yıl geçti. İşçi göçünün başlangıcından bugüne kadar geçen bu uzun süreçte göçmenler gittikleri ülkelerde yerleşik hale gelirken, göçmen kuşaklar da pek çok alanda varlık gösterdiler. Göçün beraberinde getirilenler ve yaşanılan yerlerdeki kazanımların yoğrulmasıyla ortaya çıkan Türk-Alman Sineması, çok kültürlü yapısıyla Avrupa Göçmen Sineması altında bir disiplin oluşturdu. İkinci ve üçüncü kuşak sinemacılar olarak adlandırılan Türkiye kökenli yönetmenlerin ortaya koyduğu filmler, bir anlamda Alman sinemasının yeni dönemini temsil eder konumda yapımlar oldular. Türk-Alman sinemasında özellikle 2000'li y1llardan itibaren yapılan filmler, hem göçmen bir neslin üretimi olan ulusaşırı filmler hem de yeni bir karma, "çok kültürlü ulusal" sinema olarak nitelendirilebilecek ürünler haline geldiler. Öte yandan, Türkiye yönünden "Ulusaşırı Türk Sineması" olarak bir sınıflandırma ve sahiplenme de literatürde tartışılan konular arasında yer almaktadır. 1990'da iki Almanya devletinin birleşmesiyle başlayan "Birleşme Sonrası" olarak sınırları belirlenen dönem, artık Almanya'da yetişen ikinci kuşaktan sinemacıların da üretimlerine başladığı yıllarla örtüşmektedir.

Gözde Naiboğlu², Türk işçi göçünün 60 yıllık tarihinin kazanımı olan Türk-Alman Sinemas1 hakkındaki çalışmalarıyla, Avrupa göçmen sinemasına farklı bir bakış açısı getirerek alana katkı sağlayan bir araştırmacıdır. Bu röportajda, "Post-Unification Turkish German Cinema; Work, Globalisation and Politics Beyond Representation" adlı kitabı ekseninde, ancak onunla sinırla kalmayan bir derinlemesine görüşme ile Türk-Alman Sineması'nın ortaya çıkışından Almanya ulusal sinemasındaki bugünkü konumuna kadar uzanan yeni bakış açları ve göç sinemasına dair alternatif yaklaşımlar değerlendirilmiştir.

Ayla Torun - Birleşme Sonrası dönemin arka planından kısaca bahseder misiniz? Tarihsel bağlamda sinemann gelisim sürecinde avant-gard akımın öncüsü Almanya, sonrasında rejimin sözcüsü olan propaganda sinemasinm örneği oldu. II. Dünya Savaşı sonrasindaysa iki aym devlet olarak ayrildr. 1990'lara kadar nasıl bir Alman sineması vardı? Yeni kuşak hem göcmen hem iki Almanya'nm sinemacular anlamında nasıl bir altyapını üzerine sinemasım inşaa etti?

Gözde Naiboğlu - Alman sinema tarihine baktığımızda dünya sineması açısından önemli sayabileceğimiz iki dönem görüyoruz: İlki bahsettiğiniz gibi Alman expresyonizmi olarak anılan Weimar sinemas1 (1919-1931) ikincisi ise 1960'larda Bat1 Almanya'da Oberhausen manifestosuyla başlayıp özellikle 1970’lerde zirve yapan ve 1982'de Rainer Werner Fassbinder'in ölümüyle bittiği varsayılan 'Yeni Alman Sineması' dönemidir. Bu iki dönemin

\footnotetext{
${ }^{1}$ Dr. Ayla Torun, Bağımsız Araştırmacı, E-mail: aylatorun@gmail.com. ORCID ID: 0000-0003-1675-6366

${ }^{2}$ Dr. Gözde Naiboğlu, Leicester Üniversitesi, Sanat Tarihi ve Film Bölümü, İngiltere.

${ }^{3}$ Birleşme Sonrası Türk-Alman Sineması, Temsilin Ötesinde İş, Küreselleşme ve Politika
} 
ortak noktasının biçimsel ve anlatısal deneysellik olduğunu söyleyebiliriz, ancak Yeni Alman Sineması'nı önemli kılan esas unsur bu biçimselliği politik bir duruş, söylem ve aktivizmle birleştirmesiydi.

Birleşme sonrasında Alman sinemasında bir tıkanıklık ya da estetik anlamda bir gerileme görüyoruz. Duvarın yıkılışı, soğuk savaşın bitimiyle gelen o 'iyimser', uzlaşmacı, liberal görünümlü ama aslında estetik olarak son derece banal, eleştirelliğe ya da 'öteki türlü düşünmeye' pek açık olmayan, hatta eleştirellikten kaçan bu yeni düzenin 1990'l1 yıllarda sinemaya etkisi çok açık. Yaratıcılıktan ve eleştirellikten korkan bu düzenin uzun vadede Mark Fisher'in 'kapitalist gerçekçilik' olarak kavramsallaştırdığı ideolojinin erken evreleri olduğunu söyleyebiliriz. Kültürel üretim alanında yeniliğe son derece kapali, tekrara dayalı, yani kafaları geriletmede, statükoyu dayatmakta çok güçlü bir ideoloji.

Alman sinema tarihçisi Eric Rentschler bu 90'lar Alman sinemasını 'uzlaşma sineması' olarak nitelendirir ve adı öyle de kaldı gerçekten. Romantik komediler, edebi uyarlamalar, Hollywood sinemasindaki trendlerden esinlenen ama son derece banal aksiyon filmleri ve önemli sorulardan kaçan filmlerin bu dönemde çok öne çıktı̆̆ını söyler. Hakikaten de uluslararası film festivallerinin ödül listelerine ya da hatta içeriklerine bakıldığında bu dönemde çok az sayıda Alman filminin festivallerde gezindiğini görüyoruz. Ama yok da değil. Hatta bu yazıda Rentschler tek tük yaratıcı yönetmenlerin olduğunu da söyler ve bunların içine en az iki tane Türk asıllı Alman sinemacıyı da ekler: Thomas Arslan ve Fatih Akın.

Türk-Alman sinemasının, özellikle 90’lar sonrası ikinci kuşak Türk Alman sinemasının hem anlatı dilindeki yaratıcılığı, başka türlü yaşamları, bedensel ve yüz ifadelerini; hatta, hem kişisel alanları, iç mekânları, oturma odalarını, hem de dişarıyı, sokağı, kentsel alanı gösteriş biçimindeki farklılı̆̆1, bu 90’larda daralan sinema imgeleminin dönüşmesini sağladı.

A.T. - Burada Türk Alman sinemasmm oturduğu temeli anlamak adına biraz açarsak; Türk Alman sinemasina temel olan kapitalist gerçekçilik. Alman sinemasinda da hakim diyebilir miyiz??

G.N. - Aslında konuya kavramsal açıdan girerken anılması gereken çok önemli bir kavram bence. Mark Fisher, Kapitalist Gerçekçilik ile son dönemde içinde bulunduğumuz ve açıklayamadığımız garip-gerçekçi, "kapitalizmin alternatifi yok" anlayışını kavramsallaştırdı. Hayatın her alanında hatta sinemada da kapitalizme hapsolmuş durumdayı. Hatta Zizek'in galiba bir söz vardır "Dünyanm sonunu düsünmek kapitalizmin sonunu düs̆̈̈nmekten daha kolay" diye. Mark Fisher'in anlattığı şey de gelecek kavramının, ya da imgelemin genişliğinin, geleceği düşünebilmenin, farklı birşeyler yaratmanın ne kadar zorlaştığı. Uzlaşmacı, stotükocu, yeniliğe çoğunlukla kapalı ama aynı zamanda bir taraftan da liberal görünüp, yeniliğe açıkmış gibi davranan ideolojik bir kavramdan bahsediyor. Yaratıcllıktan korkan, eleştirellikten korkan bu uzlasma sinemasinın da aslında kapitalist gerçekçiliğin bir ürünü olduğunu söyleyebiliriz.

Rentschler'in bu "uzlaşma sineması" dediği döneme bakınca, bir durağanlık, düzenle çok uyuşan hatta biraz fazla uyuşan filmlerin çoğunlukta olduğunu goruyoruz. Bunu da gelecek imgelemini tuketen kapitalist gerçekçilik bağlamında ele alabiliriz.

A.T. - Bir anlamda travmatike bir yapınn üzerinde olusan, Almanya'nun taribsel altyapısından tamamen kopuk ve kendi gündemini aktaran bir göcmen sineması ile başlayan bir süreç var, diyebilir miyiz? 1960'larda başlayan iş̧i gösüne dair filmler -1970'lerde az sayıda film olmakla birlikte-1980'li yullarda ortaya çı.maya başladr. 1990'dan sonraysa Almanya'da yetişen ikinci kuşak gögmenlerin filmleriyle artık içerden bakuşın 
sinemaya yansıdı̆̆ görülï̈or. Çalısmanıza konu olan 1990'll yullar yani Birlesme sonrası ile bu ilk dönem arasindaki belirgin aymliklar nelerdir?

G.N. - Almanya'da çekilen ve Alman sinemasının altyapısından çıkan bir filmden bahsediyorsak eğer Almanya'nın tarihsel sürecinden kopuk bir değerlendirme yapmamız bence yanıltıcı olur. Hatta aksine, ilk donem Türk-Alman sineması üzerine, Almanya'nın tarihsel bağlamı içinde hala yazılacak, söylenebilecek çok şey var. Yeni Alman sinemasıyla arasında kurulacabilecek bağlantılar da olabilir mesela. Örneğin ilk dönem Türk-Alman filmleriyle bazı Fassbinder filmleri arasında estetik, konusal, mekânsal ve hissel bağlantılar kurulabilir. Almanya'nın göçmen sineması tarihinde hep adı geçen filmlerdir Katæelmacher (Rainer Werner Fassbinder, 1969) ve Angst essen Seele auf (Ali: Korku Rubu Kemirir, Rainer Werner Fassbinder, 1974). Ama örneğin televizyon için çekilen 'Acht Stunden sind kein Tag' dizisinde gösterilen fabrika ortamları, çalışma ve özel hayat arasındaki bağ, işçiler arasındaki dayanışma gibi konular, Türk Alman sinemasının temel konularıyla çok yakından ilişkili ve karşılıklı incelenebilir.

Ben Türk-Alman sineması kanonunun biraz deneysel bir tavırla gevşetilmesinden yanayım. Bu başlık altında daha önce pek ya da hiç ele alınmayan filmler çok enteresan ve ferahlatıcı düşünme, konuşma, tartışma alanları açacaktır. Örneğin televizyon için çekilen Verlierer (Kaybedenler, Berdt Schadewald, 1987) gibi az bilinen, bugün kült kategorisine giren filmler de Türk-Alman sineması başlı̆̆ altında incelenmeye değerdir. Verlierer endüstriyel Ruhr bölgesindeki sokak çetesi savaşlarını konu alır ve heavy metal ve punk dinleyen Türk gençlerin, NeoNazilere karşı diğer metal-punk çeteleriyle kurduğu dayanışmayı anlatır. Gayet eğlenceli, thrash metal gibi yerel alt-kültürel oluşumlara değinirken ayn1 zamanda 70’ler ve 80’ler Hollywood ghetto filmlerinden de etkilenen, Almanya'daki Türkiye asıllı gençliği görmeye pek alışık olmadığımız yerlerde gösteren ve politik durusu olan bir filmdir.

A.T. - Buna Türk sinemasmdaki yansimadan bakmak gerekirse, yani Almanya'nn taribsel sürecinden kopmasalar da Türkiye'den bakıldiğında; Türkiye' den gitmişler ve oradaki ataerkil düzen, geleneksel toplum gibi değerlerin üzerine insaa edilen bir anlatım var. Yesillcam'ın da yaptı̆̆ filmler var bu dönemde Almanya Acı Vatan gibi. Tunç Okan'ın Otobüs'ü var, biraz aymksı, yenilikçi ilklerden olan. Arada anlatımı biraz. farkh olarak anlan Ayten Kuyululu ve hemen ardindan 80'lerin sonunda Tevfik Başer'in üclemesi geliyor. Bu aradaki diğer yapılanlar Yeşilcam'in filmleri. O bakımdan Türkiye'den bakuldiğında bir kopukluk var mi, Almanya'nın dışından gelerek. Almanya'da yaşadıkların mı anlatıyorlar yoksa Almanlarla beraber yoğrulan bir ortak kültü̈rü mü?

Evet, farklı bir imgelemden geliyor, o kesinlikle doğru. Ama 90'lar sonrasında ikinci ve üçüncü kuşak dediğimiz Türk-Alman sinemasıni kesinlikle Almanya'nın altyapısının içinde okumak gerektiğini düşünüyorum.

İlk kuşak Türk-Alman sinemasının 1990'lar sonrasında ikinci ve üçüncü kuşağa evrimi konusunda özellikle Deniz Göktürk makalelerinde önemli saptamalarda bulunur. Birinci kuşak filmlerin sosyal gerçekçi tonunun, bunaltıcı iç mekânlarının, temsil yükümlülüğüyle ağırlaşmış ruh hallerinin ve mağduriyet hikayelerinin, ikinci kuşakta ruh ve zihin açıc1 bir yaratıcılığa, dışarıya ve sokağa, göçmenliğin keyifli taraflarına evirildiğini söyler. Bu ilk kuşağ1 görev sineması olarak adlandırır; Şirin'in Dugunu, Tevfik Başer'in filmleri gibi filmler. Biraz sosyal gerçekçiliğe kaydığı için görev, yani görev bilerek yapılan filmler. Göktürk’ün yirmi yıl önce yaptığ1 bu saptamalar bu konudaki çalışmaların çok önünü açtı, hatta Türk-Alman sineması çalışmalarını akademik bir alt-disiplin haline getirdi diyebiliriz. Bu tartışmaların kimlik 
bağlamından çıkarılması ve tarihsel (örneğin Almanya'da çalışmanın/çalışma ekonomisinin sinemasal tarihi) ya da tematik (Almanya’ya isçi göçü ya da alt-kültürler gibi) alanlara taşınmasının çok olumlu ve zihin açıcı getirileri olacaktır.

Öte yandan, Başer'in filmleri 40 Quadratmeter Deutschland $40 \mathrm{~m} 2$ Almanya, 1986) ve Abschied vom falschen Paradies (Sabte Cennette Veda, 1989), Shirin's Hochzeit (Şirin’in Düğünü, Helma SandersBrahms, 1976) ya da Yasemin (Hark Bohm, 1988) gibi İlk dönem Türk Alman sinemas1 filmleri sosyal gerçekçi ve politik bir sinema. Belli bir sosyal durumu gösterme niyetiyle yapılmış çok erken filmler. O döneme baktığınızda Almanya'daki Türkleri ekranda görmek pek mümkün değildi, bence bu filmler o yuzden son derece önemli filmler. Bugünden bakinca fazla karanlık ve macerasız görünebilirler ama geri gidip tekrar baktığımızda yeni şeyler bulabiliyoruz. Sinema dili anlamında belki biraz didaktik ve gri filmler.

A.T. - Yine de zamanm asan anlatımlar bulunabiliyor. Sabte Cennete Veda'daki mesela, bugünkü arayışlardaki gibi o temsil edilen kadın formatından çıkmıs, içinde bulunduğu durumu aşan bir kadın. Yakın zamanda yeniden izlediğimde çok doğallıkla anlattı̆̆ın düsündüm.

Bence de kesinlikle. Hatta bu filmlerin oluşturduğu görsel-işitsel arşivin sonradan çok fazla ziyaret edildiğini soyleyebiliriz. Tabii ki bir geçmişi de yoktu bu sinemanın öyle düşünürseniz. Bunlar çok öncü filmler.

A.T. - Türk-Alman sineması olarak adlandinlan sinemann özellikleri nelerdir? Hangi aşamadan sonrasina Türk-Alman sineması deniyor ya da bu kavram için ölçek nedir siz̧ce?

G.N. - Sanırım bu kategorinin, üzerinde uzlaşılmıs, kesin bir tanımı yok ama çoğunlukla yönetmenlerin kökeni ölçek alınıyor. Yani Türk-Alman sineması deyince akla ilk olarak Türkiye asıllı Almanya'da yaşayan yönetmenler, ya da Türkiye kökenli Alman yönetmenlerin filmleri geliyor. Ama az önce de biraz değindiğim gibi- bu kategoriyi tematik olarak belirlemenin daha verimli bir yaklaşım olduğunu düşünüyorum. Yani Türk-Alman Sineması tanımı, yalnız yönetmenin biyografisinden ziyade filmlerin konusu üzerinden belirlenmeli. Türkiye'den Almanya'ya işçi göçü ve bu göçün sonrasını, kültürel, politik, toplumsal etkilerini konu alan filmler bu kategoriye dahil edilmeli.

A.T. - Almanya'da yetisen Türk-Alman nesillerin ilk kuşağa göre daha entegre ve çokkeültürlü olarak gelismeleri sonucu ortaya çıan bir melęlesme sözkonusu. Gögmen sinemasm olusturan altyapı da tabii ki bu. Türk-Alman sineması, sinirlar giderek bulanılaşan bu geçişkenliğin çekiciliği ile mi dikkat çekiyor? Burada oryantalist bakıs açılar da hala devreye giriyor mu? Yeni Türk-Alman yönetmenlerin başarssi, bahsedildiği gibi otantik temsilleri tasvir etmedeki basarilarna mi bağh?

G.N. - Çokkültürlülük, melezlik ve hatta kültürel tanımlanamazlık gibi unsurların bu filmleri çekici kıldığına şüphe yok, haklısınız. Akademik alanda özellikle 2000’ler başında melezlik, akışkanlık, çokkültürlülük, kozmopolitlik ve ulusötesilik gibi kavramlar, yeni etik, politik ve eleştirel yaklaşımlara olanak sağladılar. Çokkültürlülüğü, Batı -ya da Avrupa- merkezciliği ve bunun getirdiği hiyerarşik yapıları ve ayrımcılığı kırmaya yönelik bir proje olarak ele alırsak, etik ve politik boyutunu anlayabiliriz.

Ancak bu kavramlar aynı zamanda pazarlama etiketi olarak da özellikle 2000’lerin ilk on yılında çok sömürüldüler. Ben bu filmlerin başarısında çokkültürlülük etiketinin rolünün kısıtlı olduğunu düşünüyorum. Örneğin, en popüler Türk Alman sinemacısı Fatih Akın, çokkültürlülük hikayelerini tabi ki çok çarpıcı bir dille anlatıyor, ama bence başarısını ve 
popülerliğini mümkün kılan diğer unsurlar çok daha kuvvetli: Özgün anlatım tarzı, sinema dili, estetik maceracilığ1 ve hatta sinematik anlamda çokkültürlülüğü ki burada Yeşilçam, Hollywood Rönesansı ve Yeni Alman Sineması gibi çok farklı dönem-tarzların bileşimi var diyebiliriz, bence çok daha güçlü unsurlar. Ayrıca, Fassbinder ve Hollywood melodramının da çok büyük etkisi var. Mesela Fatih Akın'ın üzerindeki Yeşilçam etkisiyle ilgili çok fazla yazı olduğunu sanmıyorum ama Fassbinder ile Fatih Akın karşılaştırması yapılmışır. Thomas Elsaesser, bu karşılaştırmayı detaylı olarak yapar. Bu kadar farklı tonu özgün ve yaratıcı bir şekilde harmanlayan bu filmlerde 'otantik' bir temsil aramak bana çok ters ve kısıtlayıcı bir yaklaşım gibi geliyor.

Aynı şeyi, birbirinden çok farklı tarzlarda filmler yapan Thomas Arslan, Seyhan Derin ve Aysun Bademsoy için de söyleyebilirim. Bu filmlerde şeyleri 'olduğu gibi gösterme' amacı ya da kayg1sı olduğunu düşünmüyorum. Aksine bu filmleri çekici kılan, estetik alanı yaratıc1 şekillerde kurgulayarak, deneysel düşünceye ve belki de daha önce biraraya getirmediğimiz konular ve kavramlar arasında yeni bağlar kurmamıza olanak vermeleri.

Çokkültürlülük konusuna tekrar dönersek, bu yukarıda bahsettiğimiz tablonun son on ylda Avrupa'da ve hatta dünyada değiştiğini görüyoruz. Özellikle 2008'deki finansal krizden sonra başlayan tasarruf politikaları, agresifleşen neoliberalleşme, mülteci krizinin sömürülmesi sonucu güçlenen sağ popülizm gibi unsurlar yüzünden son yllarda Avrupa'da genel olarak çokkültürlülük gibi özelliklerin olumlu, çekici, toplumları zenginleştirici ve dönüştürücü boyutuna olan vurgunun çok azaldığını söyleyebiliriz.

A.T. - İkinci kusak Türk-Alman sinemacılarn odaklandiğı konular, anlatım dilindeki ve sinematografik ögelerdeki değişimden babseder misiniz?

G.N. - Konular, anlatım tarzları, modlar ve türler çok zengin diyebiliriz. Ortak bir anlatım dilinden bahsetmek çok zor. Tematik olarak bakacak olursak bazı konular öne çıkıyor: Çalışma ve yaşama şartları arasındaki ilişki, güvencesizleşme ve bunun yarattı̆̆ bedensel ve ruhsal erozyon, çalışmanın hayatı belirlemesiyle gelen yalnızlaşma ve psikolojik zayıflama, etnik ve sınıfsal kategorilerin kesişimi ve ayrıştırılması, dayanışma olasıllğı, sosyal hareketlilik hayali ve bu hayalin yitimi, polis şiddeti, ırkçılık, ev işi ve kadınların gizlenen ya da yok sayılan emeği, ataerkil yapılar, kadınlara yönelik şiddet, tabular ve önyargılar gibi. Tabi bunların yanında eğlence ve çokkültürlülügün getirdiği haz unsurları da var.

A.T. - Belki de bu yeni sinemayz anlamak ve değerlendirmek için de -yeni kuşak Türk-Alman sinemacular

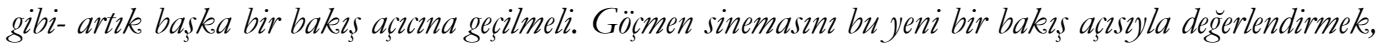
sinemaya ve alana ne gibi katkelar sağhyor?

G.N. - Temsilci bakıştan, kimliğe ve entegrasyona dayalı değerlendirmelerden uzaklaşılması gerektiğini düşünüyorum. Bu şekilde çerçevelenen değerlendirmeler genellikle filmleri hâlihazırda var olan bir Türk-Alman toplumunun sinemadaki 'iyi' ya da 'kötü' kopyaları olarak nitelendiriyor ve bu şekilde, filmlerin yukarıda bahsettiğimiz potansiyelini yok sayabiliyor. Oysa ki filmleri bu bağlamdan çıkarıp çeşitli şekillerde ele almak mümkün, filmlerin görselduysal kurgulanışındaki çeşitlilik ve zenginlik çok farklı estetik deneyimlere, düşünce deneylerine ve başka bağlamlarda tartışmaya elverişli.

Batı kültürünün çok büyük bir parçasıdır temsilcilik. Ontolojik, varoluşsal bir parçası neredeyse. Benim temsil sonrası (post-representational) dediğim şey aslında materyalist felsefecilerin, örneğin Foucault'nun, Nietzsche'nin, Deleuze'ın (özellikle sinema üzerine 
yazılarında), ve Karen Barad'in temsil eleştirilerinden harmanlanmış eleştirel bir yöntem. Bu bakışı yalnız felsefecilerin yazınlarında değil sinema teorisinde de buluyoruz. "Affect" kavramı mesela bununla çok yakından ilintili bence. İzlediğimiz şeyi; imgeyi, gerçekliğin ve halihazırda var olan şeylerin bir temsili ya da kopyası olarak görmektense, o şeylerle aynı düzlemde var saymak ve ele almak anlamına geliyor. Yani ben ne kadar gerçeksem, benim düşüncelerim ve hislerim de o kadar gerçek, benim izlediğim film de aynı gerçekliğin boyutunda diyelim. Bu anlamda post-representational yani temsil-sonrası dediğim şey sadece tarihsel bir şey ardıllıktan bahsetmiyor, temsilsel olandan sonra gelen yeni bir estetik gerçeklik var demek istemiyorum. Diğer "post”lar gibi yani post-kolonyal kavramında olduğu gibi temsilsel olanı, temsilci düşünce biçimini eleştiren ve bunun ötesine geçmeye çalışan bir yöntemden bahsediyorum. Tamamen eleştirel bir kavram aslında. Birçok eleştirel teori kavramında olduğu gibi tabii ki pratigi de degiştirmeye yönelik bir gelecek açmak isteyen de bir kavram.

A.T. - Deleuze' un sinemaya etkisi çok fazla. Tarkovski filmlerindeki zaman-imge, rüya-gerçeklik geçişleri gibi pek çok konu Deleuzian bakışla değerlendirilebildi ya da onlarla sinema anlamlandirlmaya çalışld.

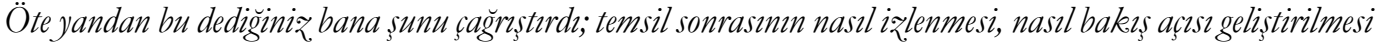
gerektiği, taa Eiseinstein'a kadar gidip "kurguyu bile bosu boșuna anlamlandirmaya uğraşmayalim, bir bakalım ne söylüyor?" diyecek kadar dişından, materyalist bakmak belki. Buradan Türk-Alman sinemacılara döndüğ̈̈müzde içinde bulunduklar durumu dramatize etmeden bir bakıs gelistirmek en önemli farklılıklar mı?

G.N. - Dramatize etmeyen de var Thomas Arslan gibi, Aysun Bademsoy gibi, ama edenler de var. Mesela Fatih Akın son derece dramatize eden hatta aşırılığı olan, çok melodramatik diyebileceğimiz filmler yapan bir sinemacı. Yine de Fatih Akın'da bir otantiklik aramanın ters bir yaklaşım olduğunu düşünüyorum. Çünkü tam tersine çok ciddi bir yaratıcılık ve yaratıcılığ1 harmanlama derdi var orada ve gerçekçilik derdi yok. Yaşamın Kıyısında'yı ele alalim mesela; bir eleştirmen bu film için Holywood senaryo doktorlarina saçını yolduracak bir senaryosu var demişti. O kadar çok tesadüf, kaderde kesişme, aşırı bir duygusallık var ki o filmde, o yüzden bu filmde bir temsil aramak bana ters geliyor. Thomas Arslan, Aysun Bademsoy gibi sinemacılar materyalist film analizine çok rahat kendilerini bırakan tarzları olan yönetmenler. Ama Fatih Akın böyle değil, çok dramatik hatta melodramatik. Ama buna rağmen sinema tarihi içinde bakınca Fatih Akın'ın o kadar farklı etkileşimleri var ki farklı farklı esinleri birleştirdiği, tamamen hisle alakalı, sizi ağlatabilecek bazen güldürebilecek hatta utandırabilecek filmler. Bunlar tamamen zenginliği ile alakalı bu sinemanın.

A.T. - Ne kadar dramatik ya da melodramatik desek de finalde her zaman çerçevenin dişına çıkzyor ve dişaridan bakmaya firsat veriyor sanmm ve dediğiniz özdeşlikleri orada yakaliyor olabilir. Yasamm Kiyısinda'da farkl kadınlarn hayatlarndan örneklerden sonra, en sonunda bir kiyıdan bakmak bile, olan biten bu istediğin gibi yorumlayabilirsin seklinde izleyiciyi ucu açı yorumlara götürüyor. Duvara Karsı'daki biber dolmasi sabnesinden sonra ne kadar materyalist denebilir bilinmez ama çok sevdiğim bir sabnedir. Ne kadar melodram anlatısı içinde de olsa dediğiniz. vurguya y aklaştı̆̆ bir nokta bep sonunda var. İster istemez. Fatih Akın'a gidiyor konu Türk-Alman sinemasi deyince.

Dediğiniz ve verdiğiniz sahne örnekleri çok doğru. Fatih Akın’in filmleri çok sevdiğim filmler. Duvara Karşı'da Boğaz kenarındaki orkestra sahnesi de benzer bir örnek. O yüzden "olan bir gerçekliği yansıtmak istedim" gibi temsilsel bir dil arayışı bu filmlerde zaten yok. Tam tersine çok yaratıc1, çok farkll. Punk ve hayatta kaybedecek hiçbirşeyi olmayan, Türk kökeniyle de bağlantısı aşağı yukarı kopmuş, 'çöpe atmış' Cahit karakterinde de bunu görüyoruz. 
A.T. - Türk-Alman sineması Göktürk' ün açtı̆g yolla kimlik bağlamından çıkarlmalı ve özellikele tarihsel ve tematik bağlamda değerlendirilmeli dediniz: Bu değerlendirmeniz̨le izlenecek yolu da öneriyorsunuz: Tematik olarak neler zihin açı olabilir sizce? Şimdiye kadar ki gördügü̈müz örneklerin disında neye değinilebilir? Yani yenisi de yapsa bir noktada bunun kimlik veya temsil bağlamında olmadiğm söylesek. de kadin sorununu işliyorsa yine ataerkilliğe dönüyor.

G.N. - Ne yazık ki kadın sorunu zaten eskimiyor ama bağlamları değiştirerek, başka bağlantılar kurarak, arşivsel araştırmalarla çok daha değişik yönler açılabilir. Aysun Bademsoy üzerine konuşmayı çok seviyorum mesela, en sevdiği sinemacılardan birisi. O kadar vizyoner ki sinemas1; onun kurduğu bağlantılar fazlaca yeni düşünceye yön verme potansiyelini taşıyor bence. Mesela Namus (2011) filmi. Namus'un konusu şiddet mağduru kadınlar ama kadınlardan ziyade erkeklerin konuştuğu bir film bu. Kadınları neredeyse hiç görmüyoruz. Bu belgeselde Aysun Bademsoy neredeyse tamamen sadece erkeklerle konuşuyor, mekanlara da uzun zaman ayırmış olsa da "konuşan kafalar" sadece erkekler. Göçmen erkekler, düşük gelir sınıfındaki Alman erkekler, ama bir yandan da devlet yapısını temsil eden yani Alman devletini temsil eden erkekler de çok fazla söz hakkı alıyor. Bu bence çok farklı bir bakış açısı, çok değişik bir yaklaşım. Çünkü temsil dediğimiz ses vermek, yer açmak, resmetmek anlamına geliyor ama temsil ettiğimiz şey, temsil kavramının içinde aynı zamanda simgeleştirmek, soyutlaştırmak, bir fikre indirgeme, ikincil ve biraz daha önemsiz hale getirme gibi birşey de var. Bademsoy bu temsilci yaklaşıma ciddi derecede direnç gösteren bir belgeselci. Bununla ilgilenmiyor, bunun yerine aktif olarak normalde kuramayacağınız, ataerkil devlet yapısıyla erkek egemenliği arasında net bağlantılar kurmaya çalışıyor ki bence çok önemli bir beyin jimnastiği bu. Namus kavramını Almanya'da tartışırken ataerkil devlet yapısı değil geri kalmış göçmen sınıflar, kültür çatışması üzerinden hep ele alınır. O yüzden bence bu filmde kendisinin getirdiği farklı bir açı var. Bu yüzden film eleştirmenleri, tarihçileri ya da akademisyenleri için de çok açık bir alan var bu yapılara bakmak için. Alman sinemasının üzerine oturtarak ya da Almanya'nın ataerkil yapısını inceleyerek bu konular çok daha yeni yerlere taşınabilir.

A.T. - Bu ifade ettiğiniz yeni bakıs açısın ideolojik olarak temsil sonrasi -post represention-kavramina dayandırdığmnza göre, ataerkil Almanya'y ortaya koyarak aslında köke iniş bu. Sorunun kaynağmm bilirsek cözmek belki daha kolay olacak. Temsilden bakezyoruz bep geleneksel aile yapısina ama esas sorun ataerkillik. değil mi?

Evet temsil sonrası yöntemini buluyorum ben Aysun Bademsoy'un filmlerinde. Ataerkilliğin başka kültürleri ötekileştirmek icin araçsallastırılmasına karşı çıkıyor ve çok daha derin ve geniş boyutlu bir eleştirisini yapıyor. Namus bu yüzden Alman ordusunun yemin töreniyle başliyor mesela.

A.T. - Temsilci bakıs açısmın Türk-Alman sinemasmdaki filmlerin potansiyelini yok saydı̆ğnı̨ söylediniz: Türkiye'den gös sinemasına baktı̆̆mızda gördüklerimiz biraz daba farki. Alman akademik yazınndaki bakus acısi nasil?

G.N. - Özellikle son on yılda değişik bakış açılarını görüyoruz. Ingilizce ve Almanca akademik yayınlarda kesinlikle temsilin dişına çıkmıs bir bakış açısı var. Örnegin Barbara Mennel, Angelica Fenner, Marco Abel, Nilgün Bayraktar, Mine Eren ve Ömer Alkın'ın çalışmaları gibi çok yeni bakış acçları getiren bir akademik yazın var. Almanya'da bi’bak kolektifi de çok ilginç gösterimler ve yayınlar yapıor. 
504 Göçün 60. ynlinda Türk-Alman Sineması: Gözde Naiboğlu ile Röportaj

A.T. - Belgesel sinema, göç konusunu genellikle taribsel anlatı ve yaşam pratiğinin sözlü ifadesi olarak ele alır. Belgesel filmleri incelemenizde gös sinemasinda tekrar eden temalar olan anayurda (Heimat) dönüs, namus suclar ve melezlike ve entegrasyon temalarm ele aldını: Incelediğiniz filmlerde, özellikle Bademsoy'un temsil sonrası belgeselciligi politik bir strateji olarak kullanımına dikekat çekiyorsunu₹. Toplumsal yapulan kesfetmek için insan diş alan ve materyalist estetiğe başvuran, klasik anlatıdan uzaklaşan bir sinema dilinden bahsediyorsunuz: Burada değissen nedir, değerlendirmeniz̧ açar misını??

G.N. - Bademsoy bence son derece özgün bir belgesel sinema dili yarattı; filmlerindeki materyalist estetiğin çok güçlü olduğunu düşünüyorum. Kişilere, sokaklara, mekanlara, 'olay yerlerine', dışarıya ve yasama alanlarına gösterdiği aşırı diyebileceğimiz estetik hassasiyetin, neyin görülebilir, neyin hissedilebilir olduğuna yaptığ vurgunun, az önce bahsettiğim yeni düşünsel, eleştirel ya da duygusal bağlantılar kurmaya yönelik çabalarda kullanılabilecek çok kuvvetli stratejiler olduğunu söyleyebiliriz. Bence bütün filmlerine mevcut düşünce zincirini ayrıştırıp yeni bağlantılar kurma mücadelesi hakim, ama özellikle de namus cinayetlerini konu alan Ehre (Namus 2011) ve NSU cinayetlerinin (*Almanca Nationalsozialistischer Untergrund - NSU, Almanya'da faaliyet gösteren aşırı sağc1 ve 1rkçı görüşe sahip neonazi silahlı grup. Neonazi seri cinayetleri, 2000-2006 arası Almanya'da gerçekleşen irkçı seri cinayetler dokuz veya on kişinin ölümü ve bir kişinin yaralanmasıyla sonuçlanmıştır. Saldırılar Türk göçmenleri ve bir Yunan göçmeni hedef almıştır. Saldırılardan Nasyonal Sosyalist Yeraltı (NSU) isimli neonazi örgütü sorumlu olarak öne çıkmıştır.) sonrasını konu alan Spuren (İzler 2019), odağını beklenenden farklı alanlara çeviren, bu sayede de izleyiciyi beklenmedik bağlantılar kurmaya yönlendiren çok çarpıcı filmler.

A.T. - Film anlatısında sadece kurmaca değil, belgeselin çok önemli bir yeri var. Ancak günümüz çağdaș sanatıyla daha çok anliyoruz ki bir ifade aracı olarak film sadece bunlardan ibaret değil. Öte yandan, gös sineması çağdaş sanatın ele aldiğg konularla da örtüşüyor. Incelemenize video yerlestirmeyi de dabil ederek, bu anlamda yeni bir alan açyorsunuz. Neden buna gerek gördünüz?

G.N. - Ekran kültürleri çok hızlı bir değişim içinde. Hep de böyle oldu belki ama özellikle dijital sonrasında çok hızlı bir evrim hakim. Sinema, televizyon, galeri filmleri ya da video yerleştirmeler her ne kadar farklı yöntemler, araçlar, mekanlar ya da sistemler kullansa da bence ortak bir görsel ve işitsel arşive katkıda bulunuyorlar. Benim ilgimi çeken de bu görsel-işitsel arşivi, farklılıklarını tamamen göz ardı etmeden ama aralarında stratejik bağlantılar kurarak değerlendirebilmek. Bu bağlantılar çoğu zaman hiç yoktan da yaratılmıyor aslında. Örneğin, Aysun Bademsoy belgesel sinema alanında filmler yapıyor ama video ve enstalasyon sanatçısı Harun Farocki ile arasında yöntem açısından ortaklık kurmak mümkün -Bademsoy, Farocki'nin bir dönem hem öğrencisi hem de asistanıdı. Benzer bağlantıları kurmaca sinemacı Petzold ve Bademsoy, ve Petzold-Farocki arasinda bulmak da mümkün-.

Ekran kültürlerinin birbirlerinden ayrısan tarafları olsa da, bir arada ele alınmalarının da gerekli olduğunu düşünüyorum. Çünkü teknolojiyle birlikte çok hızla evriliyorlar, örnegin streaming yayınlar bugün sinemanın yerini büyük ölçüde aldı. Almanya'da zaten ekran kültürleri arasında hep bir geçirgenlik vardı. Alman televizyonlarının bağımsız sinemaya desteği çok fazladır. Fatih Akın, Thomas Arslan ve Aysun Bademsoy örneğin televizyon fonlarıyla film yapmaya başlamış yönetmenler. ZDF'in 'Das kleine Fernsehspiel' adi altında genç, bağımsız, alternatif sinemacılara verdiği destek fonlarının Alman sinemasına son 40 yıldır katkısı çok büyük. Enstalasyon ve galeri filmlerine gelince; alternatif, deneysel sinemanin şu an kendini en rahat hissettiği ortam bu aslında. Farocki'nin de bu alanı seçmesinin nedeni budur. Çok radikal ve deneysel bir sineması olduğu için, sinemadan, televizyondan başlayıp sonradan galeriye

Göç Dergisi 
dönmüş bir yönetmen. O yüzden görsel-işitsel bağlamları çok gevşek bir şekilde ele alıp ortak bir arşive katkıda bulunduklarını görmek özellikle Almanya bağlamında çok çok mümkün.

A.T. - Artık yerleşik bale gelmiş kusaklarm ürettiği Türk-Alman sinemasi, halen ulusötesi sinema kapsamında mi değerlendirilmeli, yoksa geçen süreçte artık çok kültürlü bir ulusal sinema olduğu söylenebilir mi?

G.N. - Nereden baktı̆̆ınıza bağlı ancak çok kültürlülükten ziyade ulusötesi başlı̆̆ı daha çok kullanılan bir araç olabilir, transnational sinema. Şöyle değerlendirmek gerekirse; Alman sineması içinde bir alt alan mı diye bakarsak buna, kesinlikle evet. Çoğunluğu Alman altyapısından çıkan, Almanya'nın yerel fonlarıyla yapılmış filmler. Bir çoğu da şu anda ikinci ve üçüncü nesilden bahsediyoruz, kendini Alman olarak tanımlayacak yönetmenlerdir. Bu yüzden Alman sineması çalışmaları içinde genelde araştrılıyor ve orada daha çok kaynak var. Bir ulusal başlığın altına koyacaksak -koymak zorunda değiliz ama eğer koyacaksak- bence Almanya altında olmalı. O kesinlikle öyle. Çoğunluğu zaten Berlinale'de açılışını yapmış, Almanya'da gösterilmiş, Alman TV'lerinin fonlarıyla yapılmıs. İstenirse başka başlıklarla da bakmaya açıktır tabii.

A.T. - Türk-Alman sinemasınn geleceğini değerlerdirmek gerekirse; Neredeyse 60 ynldır Almanya'da yaşayan bir Türk toplum var. Bu toplum artık yerleşik ve Türk-Alman denen tanmlama artı sadece köken bağına dönüsmüs durumda. Köken bağlamından çıan bu entegre kusaklardan sonra sanyorum ulusaşırıdan öteye ulus-sonrası (post-national) sinema tartışmalar içinde değerlendirilecektir.

G.N. - Alman sinemasının geleceği hatta bugünü kesinlikle çok kültürlü. Berlinale - Berlin Film Festivali'nin programlarına bakacak olursak, günümüzdeki Alman sinemasının en öne çıan, en heyecan verici hikayelerinde ya göçmen asıllı sinemacıların isimlerini görüyoruz ya da göçmenlik deneyimlerini konu alan filmler buluyoruz. Belki göçmen sineması bakış açısından bakarak arıyorum da buluyorum diyebilirsiniz belki ama öyle değil, bahsettiğim şey çok net. Alman sinemasından çıkan en başarılı, ödül alan yeni filmlerin çoğu ya göçmenlikle alakalı olan ya da göçmen sinemacıların yaptıkları filmler. Mesela Afgan asıllı Burhan Qurbani'nin Berlin Alexanderplatz (2020) filmi çok başarıliydı son zamanda. Maria Speth'in göçmen çocukların eğitimini konu alan filmi Herr Bachmann und seine Klasse (2021) de aynı şekilde. Christian Petzold'un Transit (2018) filmi de göçmen konusuna eğiliyor. Mehmet Akif Büyükatalay'ın Oray filmi çok başarılı oldu, en iyi ilk film ödülünü aldı hatta Berlinale'de. Ayrıca mesela festivalin alt başlıklarından Perspektive Deutsche Kino başlı̆̆ı, sadece çağdaş Alman sinemasina bakar. Orada görüyorsunuz ki son senelerde neredeyse hep göçmen asıllı sinemacilar bu kategorinin programına hakim olmuş.

A.T. - Bu kadar göcmenle yaşamıs, yogrulmus bir ülke, sonuçta her ülkeden gelenlerin üretimlerini damitıyor ve olması gereken bir noktaya gidiyor belki de. Özü zaten misafir iş̧ilik yani iş̧ilik ve çalısma yaşam olan bir göçün sineması bu aslinda. Ancak çalısma hayat hakkenda göcmenlerin ve özellikle Türk işçilerin ezilmesini anlatan Gunther Walraff' in kitabyyla aym adl En Alttakiler belgeseli konuşulur. Emek ve iş̧i göçünün sinemaya yansımasım incelemeniz anlaml bir bakıs açısı. Calısma ekonomisi ve emek yönüyle değerlendirdiğinizde nasıl bir yansima var?

G.N. - Türk-Alman sineması üzerine çalışmaya aslında bu konuyu irdeleme amacıyla başlamıştım. Özellikle birinci kuşağın post-Fordist çalışma şartlarına adapte olma arayışı filmlerde çok öne çıkan bir konu. Örnek vermek gerekirse, Thomas Arslan'in Geschwister (Kardesler) ve Dealer filmleri. Bu ikisi Berlin Üclemesi'nin filmleri. Taksi şoförü olan babanın 
tehlikeli çalışma ortamlarında yaşadığı derin endişe. Bu yüzden çocuklarıyla anlamlı bir ilişki kuramaması. Dealer'da sosyal yukarı hareket baskısı yüzünden kebapçı olmak istemeyen bir karakter, kebapçı gibi güvencesiz bir çalışma ortamını reddeden baş karakterin, daha çekici görünen uyuşturucu tacirliğini seçmesi ve resmen iki ayrı güvencesizlik arasında seçim yapması gibi konular vardı. İşte bu ikinci, üçüncü kuşağın iyice hırçınlaşan güvencesizlik ortamında yaşama mücadelesi, bir yandan etnik kökenlerinden kaynaklanan kimlik baskıları, arzunun bu ortamda yön buluşu gibi meseleler çıkıyor bence bu filmlerde. Bu gibi konuların bu filmlerde çok farklı ve yaratıcı şekillerde; didaktik, sosyal gerçekçilik ya da dayatılan bir lineer işleyen, alışılageldik kurguyla değil de daha gündelik, banal olana dikkat kesilip, çıplak gözle görülebilecek detaylar olduğuna 1srar eden bir stille işlendiğini görüyoruz. Filmlerdeki bu vurgu nedeniyle bu konuya yaklaşmak istedim. Aslında bu dediğimi hem Thomas Arslan'in Berlin Üclemesi'nde hem de Christian Petzold'un -Jerichow' 'unda mesela, görüyorsunuz bu çalışma koşullarının Türk asıllı Almanlara yaptığını. Bademsoy'un filmlerinde de buluyoruz bu konuyu ve banale keskin bakış yöntemini de buluyoruz. Seyhan Derin'in Ben Annemin Kızıyım'i annesinin ve babasının işine odaklanan, çok güzel bir belgesel. Yine genelde memleket, arada kalma, kültürel ikililik gibi konular altinda ele alındı ama bence tamamen çalışma üzerine olan bir filmdi bu. Babası fabrikada çalışırken bir is kazasinda sakatlaniyor ve erken emekli olmak zorunda kaliyor, annesi bu yuzden hem babasinin bakimini hem de evin gecim masraflarini ustleniyor. Annesiyle sosyal yardim merkezinde sira beklerken roportaj yapiyor mesela. Çalışma ve çalışmanın etkisi, göçmenlerden, Türk-Alman sinemasından bahsederken biraz unuttuğumuz bir konu demek istedim.

Arslan, Petzold ve Bademsoy'un bu alanlara eğilmesi tesadüf değil aslında, çünkü üç yönetmen de Harun Farocki'nin öğrencisi olmuş. Farocki de yine göçmen kökenli ama Almanya'da çok sayg1 duyulan bir deneysel belgesel film yönetmeniydi. Her üçü de Farocki ile çalışmış. Farocki'nin işlerinde, yazılarında da hep bu mücadele hakimdir. Görsel alanın kullanımı, görsel alanın neyi gösterip neyi gizlediğinin hep altını çizer Farocki. O yüzden bir tesadüf değil bu üç yönetmenin tamamen farklı biçimlerde bu konuya eğilmesi ve ama yine ortak bir noktalarının olmas1.

Almanya'ya işçi göçünden ve sonrasından bahsederken, göçmen işçiliğin, çalışma şartlarının zorluğunun, sonrasında bıraktığı bedensel ve ruhsal izlerin ne politik ne de gündelik söylemde Almanya'da yer bulmadığını görüyoruz. Bu stratejik bir seçim, hatta ideolojik bir seçim. Bunun yerine dikkati inatla kültürel farklılıklara, entegrasyona çevirmek sorumluluğu tabii ki tamamen göçmene birakmak oluyor. Entegrasyon tamamen göçmenin sorumluluğu - "devlet kendisinden beklenen herşeyi yapt1, her türlü destek sistemini yerine oturttu, buna ragmen entegrasyon sorunu yaşanıyorsa sorun kültürel farklılıklardadır” alt anlamını taşıyor bu söylem. Oysa ki bu insanlar oraya çalışmaya gitmişler ve çok ağır koşullarda çalışıp, Almanya'nın “ekonomik mucizesine” imza atmasını sağlamışlar. O yüzden de Türkiye'den Almanya'ya olan işçi göçü ve sonrası ile alakalı filmler aynı zamanda vahşi kapitalizm içinde yaşama ve var olma çabası üzerine filmler. Neden önemliler, çünkü gündelik söylemde kendine yer bulamayan konular bunlar. O yüzden estetik görsel, işitsel alanda yer bulmasının önemli olduğunu düşünüyorum. 